\title{
Statistical Errors in a Research of Clothing and Textiles
}

\author{
Kyoung-Ho Choi*, Jin-hee Choi ${ }^{* *}$ \\ Dept. of Basic Medical Science(Statistics Major), Jeonju University* \\ Dept. of Fashion Business, Jeonju University ${ }^{* *}$ \\ 의류학 연구의 통계적 오류 \\ 최경호 ${ }^{*}$, 최진희 ${ }^{* *}$ \\ 전주대학교 기초의과학과 ${ }^{*}$ 전주대학교 패션산업학과 ${ }^{*}$
}

\begin{abstract}
The purpose of this study is to examine the statistical errors, which may occur in the process of applying statistics, by major stage of research, for greatly contributing to promoting research power through rightly utilizing statistics at the point of time that the application of statistics is increased in the research of clothing and textiles. As a result, it confirmed that there are many errors by each stage.

First, it is a point that there was not any research that mentioned on the impact of analysis in the researches, which test the appearance of significance based on the collected data through experiment or survey. Second, the existence of mechanical description which is monotonous as well as not applying right analytical method in factor analysis. Also, even in case of cross tabulation, there was no hypothesis establishment.
\end{abstract}

Key Words : Statistical error, power analysis, clothing and textiles, factor analysis

요 약 본 연구는 통계적 방법의 올바른 사용을 통해 의류학 분야 연구결과의 과학성과 윤리성을 높이는데 도움을 주고자 실시되었으며, 나아가 본 연구가 통계적 방법을 활용하는 의류학 관련 연구 발전에 기여하는데 의의가 있다. 연구 결과는 다음과 같다. 첫째, 통계적 방법의 적용이나 통계패키지의 활용과정에서 나타나는 오류는 의류학 관련 연구에서도 예외는 아니었다. 이에 본 연구에서는 한국의류학회지를 대상으로 연구과정에서 자주 발생할 수 있는 통 계적 오류에 대해서 알아보았으며, 그 결과 각 단계별로 많은 오류가 있음을 확인하였다. 둘째, 요인분석 등에 있어 올바른 분석방법을 적용하고 있지도 않을 뿐더러, 천편일률적으로 기계적인 기술을 하고 있었다. 또한 교차분석의 경 우에도 가설설정이 없으며, 검정의 내용을 혼동하는 경우가 많았다.

주제어 : 통계 오류, 분석력, 의류직물, 요인 분석

\section{Introduction}

The clothing \& textile science is one part of home economics with the purpose of improving home management ability or of enhancing quality of life

Received 20 February 2014, Revised 25 March 2014 Accepted 20 April 2014

Corresponding Author: Jin-Hee Choi(Jeonju University)

Email: jhchoi@jj.ac.kr

ISSN: $1738-1916$ through family life. As the academic science was begun with the aim of a rational clothing habit within family[8], all the fields related to clothes and apparel material, and personal articles(hats, accessories, shoes, etc.) become the subjects of research. Specifically, the

(C) The Society of Digital Policy \& Management. All rights reserved. This is an open-access article distributed under the terms of the Creative Commons Attribution Non-Commercial License (http://creativecommons.org/licenses/by-nc/3.0), which permits unrestricted non-commercial use, distribution, and reproduction in any medium, provided the original work is properly cited. 
clothing \& textile science is having the main contents as design field(costume design, clothing construction, textile design, illustration, display, etc.), which corresponds to the artistic aspect, as costume history, costume aesthetics, costume social psychology, apparel products, which correspond to the aspect of humanities and social science, and as textile science, fabric science, costume environment science, sewing science, etc. which correspond to the aspect of natural science.

In the meantime, a research related to clothing and textiles can be said to be the process of seeking scientific and logical answer with diverse research methods on many contents in the above. Accordingly, like other researches, even a research of clothing and textiles is a series of scientific research process, which establishes hypothesis for solving problem from recognizing a problem, carries out experiment (or survey) for verifying the hypothesis, and solves the perceived problem by deciding on whether or not adopting or rejecting the hypothesis by gathering many materials in the experimental process. By the way, one of the methodologies, which is essentially used in this process, is statistics.

The wrong use of statistics may reach the outcome of violating some ethical duties such as honesty, objectivity, accuracy, and public disclosure. If the erroneous use of statistics is the outcome of having deceived intentionally, it is classified into misconduct. Making up false outcome or nonexistent data corresponds to fabrication. An act of artificially manipulating, transforming and deleting research data or results corresponds to falsification. The wrong use of statistics of having not been accompanied by intentional deception can be regarded as serious deviant act of escaping from the practice of a research, which is allowed as pure mistake, incompetence, and prejudice[11].

Accordingly, the purpose of this study that is to examine statistical errors, which may occur in the process of applying statistics, by major stage of

\section{$\langle$ Table 1〉 Checklist for evaluating statistical errors}

1. Scope of using statistical technique

(1) Non-use (2) Descriptive statistic (3) Inferential statistic

2. Kinds of the applied statistical techniques
(1) $\chi^{2}$ test
(2) Fisher's exat test
(3) t-test
(4) paired t-test
(5) Analysis of variance
(6) Pearson's correlation coefficient
(7) Spearman's rank correlation coefficient
(8) Regression analysis
(9) Survival analysis
(10) Non-parametric method

3. Validity of applying statistical technique

(1) Error of omission

(1) Insufficient description on basic data

(2) Insufficient description on the used statistical processing technique

(3) Insufficient description on power and confidence interval

(2) Error of commission

(1) Inappropriate description on representative value and dispersion

(2) Use of inappropriate analytical method

(a) In case of repeatedly using t-test without correction

(b) $\mathrm{T}$-test without considering independence of variable

(C) Commission of $\chi^{2}$-test in number of insufficient samples

(d) In case of being not considered appropriate multiple comparison after analysis of variance

(e) Analyzing non-parametric data parametrically

(f) Use of statistical method that isn't suitable for character of data

(3) Hypothetical testing that was overlapped to be commissioned

(4) Question that was induced unfairly

(a) Wrong use of statistical terminology

(b) In case of not mentioning the limit with extrapolating the findings in general group 
〈Table 2〉 Stage and contents in occurrence of statistical errors in a research of clothing and textiles

\begin{tabular}{|l|l|}
\hline \multicolumn{1}{|c|}{ Stage } & \multicolumn{1}{c|}{ Contents } \\
\hline 1. Design of research & $\begin{array}{l}\text { In order to be collected data in a form available for statistical analysis } \\
\text { for achieving research objective }\end{array}$ \\
2. Sample size determination & $\begin{array}{l}\text { Whether the sample size was made through power analysis } \\
\text { 3. Application of analytical method } \\
\text { situation } \\
\text { 4. Use of terminology }\end{array}$ \\
$\begin{array}{l}\text { In order to be signified the statistical principle and to be clearly } \\
\text { expressed the application of the meaning in terms. }\end{array}$ \\
$\begin{array}{l}\text { In order to be made clear in the analysis of accurate description and } \\
\text { causality on representative value and dispersion }\end{array}$
\end{tabular}

research, with the aim of greatly contributing to promoting research power through rightful utilizing statistics at the point of time that the application of statistics is increased in researches of clothing and textiles. Especially, the aim is to examine even about the power analysis which includes a problem about sample size determination given the experimental design for the group-based comparison. As the power analysis implies the method that a researcher uses at the stage of planning a research for deciding on proper sample size, it is a method of deciding on number of sampling subjects by using significance level, power, effect size, and data analysis plan [8]. In the researches related to clothing and textiles so far, there are few researches that clarified statistical error, which is repeated often in the process of research including appropriateness of sample size. Hence, this study's purpose is to discuss problems in the power analysis and the statistical aspect targeting 'Journal of the Korean Society of Clothing and Textiles,' which is the representative academic journal among journals relevant to clothing and textiles being published domestically.

Accordingly, the primary purpose of this study is to give help to increasing scientific characteristic and ethics in the findings through the right use of statistical method. Furthermore, this study has significance in contributing to development in research related to clothing and textiles with application of statistical methods.

\section{Related Works}

There are many researches that addressed the misuse of statistics in a research of all the fields. As they are researches by [10], [13] and [15], all are researches on the fields related to health and medical care. As for the checklist for evaluating statistical errors out of this, the checklist for inspected errors, that resulted while applying statistical method based on a research by [13]. In the meantime, arranging the stage and contents that error can be created in statistical application in a research of clothing and textiles based on the checklist in [12] and on $<$ Table $1>$, they are as $\langle$ Table 2$\rangle$.

\section{Research Method}

\subsection{Research subjects}

This study selected 'Journal of the Korean Society of Clothing and Textiles' particularly as the major source of this study in order to grasp the present status of using a method of power analysis in a research of clothing and textiles. The Korean Society of Clothing and Textiles, which was organized in 1976 and then issued its first issue in May of 1977, is the society possessing the country's largest members truly to the name. The Journal of the Korean Society of Clothing and Textiles is being recognized the academic value such as being registered as an academic journal by 
National Research Foundation of Korea in 2001. However, an effort for the detailed part shouldn't be saved for becoming the internationally acknowledged academic journal(SCI, etc.). For example, even what making sure that there is no statistical error in a thesis that is reported in the Journal of the Korean Society of Clothing and Textiles can be considered as a part. Accordingly, it selected the Journal of the Korean Society of Clothing and Textiles as the analytical subject.

\subsection{Analytical method}

Theses that became the subjects of evaluation, were set for researches that used statistical methods such as group-based comparative research t-test, multiple comparison, factor analysis, and cross tabulation among those from the January issue (Vol. 35, No. 1) in 2011 to the May issue (Vol. 35, No. 5). The analytical frame of this study was based on $<$ Table $2>$ research design is the first stage of using statistics at the stage of processing a research. Quality of research data is determined by the prior plan for research, careful data collection, and management process. Accordingly, the research design needs to be made in order to have collected data in a form available for proper statistical analysis for achieving research objective. As sample size is what is related to power analysis, it should be decided by using significant level, power, effect size and others [8]. A method, which is much utilized generally as a method of power analysis for obtaining sample size, is Cohen's method [4]. Regarding the application of analytical method, there is a need for examining about whether the basic assumption of statistical technique, which aims to be applied, is satisfied. For example, the validity of analytical outcome is decided according to the appearance for satisfying the basically demanded conditions and assumptions in the statistical analysis, which aims to be used. Thus, there should not be unreasonable application with failing to satisfy assumption of statistical processing technique[10]. Moreover, as for test of statistical significance, there is a need of right application along with definite understanding about significant level and significant probability. In this way, even the proper and right use of terminology becomes a factor of reducing occurrence of statistical errors. Finally, one of errors, which are made often in describing analytical outcome, is the confusion of standard error and standard deviation. It is different in a sense that the standard deviation implies measurement of dispersion on the measured data and that the standard error implies dispersion (accuracy) of estimators [1].

\section{Results and Discussions}

In the theses as analytical subjects, not many researches clearly specified a measurement tool such as questionnaire. Thus, it wasn't easy to evaluate whether data collection was made in order to be formed statistical analysis conforming to research objective. However, there was not any research describing power analysis. Accordingly, discussing about power analysis targeting the Journal of the Korean Society of Clothing and Textiles is regarded as insignificant. Hence, it analyzed focusing on sample size determination.

\subsection{Sample size determination}

Early [3] offered the general ground available for deciding on to some extent the sample size is needed roughly for experimental research. What fixes error to 0.05 or 0.01 and error to 0.2 is the rational establishment that is being used given just a research rather than the standard, which needs to be certain so in general [5]. For example, given inducing the formula of sample size determination to test statistical significance on the mean difference between two groups, it is as follows [17]. First of all, when using two-tail test as for the mean comparison between two 
groups (c: control group, t: treatment group), null hypothesis $\left(H_{0}\right)$ and alternative hypothesis $\left(H_{1}\right)$ are as follows, respectively.

$$
H_{0}: \mu_{\text {대 }}-\mu_{\text {실 }}=0, \quad H_{1}: \mu_{\text {대 }}-\mu_{\text {실 }} \neq 0(1)
$$

If significant level $(\alpha)$ is given when knowing common variance $\left(\sigma^{2}\right)$ of two groups, the null hypothesis is rejected in the following case.

$$
\left|\frac{\mu_{\text {대 }}-\mu_{\text {실 }}}{\sigma / \sqrt{2 n}}\right|>z_{\alpha / 2}(2
$$

Here, $z_{\alpha / 2}$ is the value of the point of corresponding to $100(\alpha / 2) \%$ in the standard normal distribution curve that is 0 in the mean and 1 in the variance. And under the alternative hypothesis, the power $(1-\beta)$ is as follows.

$$
1-\beta=\Phi\left(\frac{\sqrt{2 n}\left(\mu_{\text {대 }}-\mu_{\text {실 }}\right)}{\sigma}-z_{\alpha / 2}\right)+\Phi\left(-\frac{\sqrt{2 n}\left(\mu_{\text {대 }}-\mu_{\text {실 }}\right)}{\sigma}-z_{\alpha / 2}\right)(3)
$$

Here, $\psi$ is the cumulative probability function in the standard normal distribution curve that is mean 0 and variance 1 . Accordingly, the power is as follows given neglecting value smaller than $\alpha / 2$

$$
1-\beta \simeq \Phi\left(\frac{\sqrt{2 n}\left(\mu_{\text {대 }}-\mu_{\text {실 }}\right)}{\sigma}-z_{\alpha / 2}\right)
$$

Thus, sample size of aiming to be obtained from above equalities $\mathrm{n}$ is as follows

$$
\begin{gathered}
z_{\beta}=\frac{\left(\mu_{\text {대 }}-\mu_{\text {실 }}\right)}{\sigma / \sqrt{2 n}}-z_{\alpha / 2}(5) \\
n=\frac{2\left(z_{\alpha / 2}+z_{\beta}\right)^{2} \sigma^{2}}{\left(\mu_{\text {대 }}-\mu_{\text {실 }}\right)^{2}}(6)
\end{gathered}
$$

Taking an example of a research by [14], the purpose was to be conducive to sample size determination in the above. This study randomly fixed sizes of $\mathrm{co}^{-}$ed girl students and girls' high school students in the status of not having any comment on power analysis, which is demanded in obtaining sample size necessary for data collection. Given suppose the two-tail test even if making significant level 0.05 in the analysis on evaluation of satisfaction with school uniform, the minimum sample size by each group for testing statistical significance in two groups can be known to be 393 people from < Table 3>. However, an increase in error is concerned by testing through using sample size in nearly $1 / 2 \sim 1 / 3$ level in reality.

〈Table 3〉 Sample size () of being demanded
given independent sample t-test
(two-tail)
\begin{tabular}{|c|ccccccccc|}
\hline & \multicolumn{1}{c}{ Relative } & size of an experiment effect \\
& 0.2 & 0.3 & 0.4 & 0.5 & 0.6 & 0.7 & 0.8 & 1.0 \\
\hline$=0.05$ & 393 & 175 & 99 & 64 & 45 & 33 & 26 & 17 \\
$=0.01$ & 586 & 259 & 148 & 95 & 67 & 49 & 38 & 25 \\
\hline
\end{tabular}

\subsection{Application of analytical method}

Selecting analytical method that conforms to research objective out of the whole process in a research is important more than anything. That is because inducing conclusion by applying wrong analytical method at any moment on the collected data can lead to making a mistake twice. According to research by [6], in a research for the wearing evaluation with suggesting diverse pants patterns for men in the early $20 \mathrm{~s}$, the wearing evaluation was carried out on 6 kinds of pants by applying 8 men in the early 20s. In other words, it carried out subjective wearing evaluation after allowing each men to wear 6 kinds of pants in all and examined whether there is statistical significance of 6 kinds of pants on evaluation item. By the way, ANOVA was carried out for this. Still, this data is the one that is unavailable for carrying out ANOVA. In this case, evaluation was carried out after allowing 8 people to wear all 6 kinds of pants, 
thereby corresponding rather to paired sample. And, the number of samples is relatively small. Thus, it may be desirable to apply 'Wilcoxon signed rank test'.

Next, there is factor analysis as for the analysis of being misused often in a research of clothing and textiles. Moreover, given having aimed at principal component analysis, the factor rotation shouldn't be designated [16]. However, as seen in some error examples below, many researches are having mechanical expression and analysis.

- Kim and Jin [7] : As a result of carrying out orthogonal rotation by Varimax through extracting factor as principle component analysis......

- Moon and Youn [9] : As a result of utilizing principle component analysis by Varimax rotation according to the standard of refinement for factor analysis.....

- Park and Park [12] : As a result of making orthogonal rotation by Varimax method as the factor analysis method uses principle component analysis method......

- Jung and Lee [6] : As a result of carrying out factor analysis by principle component analysis and Varimax rotation method......

- Kim et al. [18] : Extracting factor whose eigenvalue is more than 1 by the principle component analysis with Varimax rotation....

- Chung [2] : Principle component factor analysis was carried out by Varimax rotation.....

Of course, as in the research by [7], there is a research sometimes that applied right statistical analysis such as extracting factor with ordinary least square method given factor analysis. However, as in a research by [2], the misuse of statistics was shown seriously in many researches such as having even a case of utilizing the misused terminology called 'principle component factor analysis.'

As a method for examining significant difference among more than 3 groups, ANOVA is carried out. If the significant difference is recognized as a result of it, post-analysis is carried out. By the way, most of the researches, which carried out post-analysis, including [9], used Duncan method as post-analysis method. However, multiple comparison method needs to select reasonable method based on the point of time with the aim of multiple comparisons, the specific comparative form, and the appearance of being same in number of samples in each group.

\subsection{Use of terminology and results description}

The right expression on statistical terminology in expressing the contents and results of research is necessary to deliver a meaning accurately. At the same time, the wrong use of terminology may drop reliability of research. A case that the use of terminology is wrong was not found much. However, there was even a case that the standard deviation was wrongly used as deviation. In case of [12], the mean and the deviation are being described in comparing characteristics between university students in their 20s and office workers. This is considered probably that the standard deviation was wrongly recorded.

〈Table 4〉 Educational level and marital life
satisfaction
\begin{tabular}{|c|c|c|c|}
\hline & Poorness & Satisfaction & Good \\
\hline University & 72 & 112 & 245 \\
High School & 65 & 90 & 120 \\
Middle School & 95 & 103 & 98 \\
\hline
\end{tabular}

〈Table 5〉 Subject preference

\begin{tabular}{|l|c|rc|c|}
\hline & English & Language & Art & Mathematics \\
\hline Boys & 100 & 80 & 70 \\
Girls & 110 & 60 & 80 \\
\hline
\end{tabular}

The fundamental difference between $<$ Table $4>$ and $\langle$ Table 5$\rangle$ is in the process of sampling. A case of $<$ Table $4>$ is what divided posteriorly according to educational level after looking into 1,000 survey 
subjects at once. <Table 5$\rangle$ is what surveyed by dividing it into boy students group and girl students group from the beginning. This plan corresponds to the contents that will need to be embodied at the stage of designing research. If data were collected as <Table $4>$, independent test needs to be carried out. Given having been collected as $\langle$ Table 5$\rangle$, homogeneous test needs to be carried out. The null hypothesis in the independent test is ' $H_{0}$ : Educational level and marital life satisfaction are independent'. The null hypothesis in the homogeneous test is ' $H_{0}:\left(p_{i 1}, p_{i 2}, p_{i 3}\right)=\left(p_{11}, p_{12}, p_{i 3}\right)$ '. As can be seen in the expression of null hypothesis, two tests are different in objectives and contents.

Examining [9] who researched into the influence of consumption value in fashion luxury brands upon intention of maintaining brand relationship, the cross table in <Table 6> was formed according to the marriage appearance and the fashion luxury brand segmented group by surveying 325 female consumers in their 20s $\sim 50$ s nationwide. This case corresponds to independent test when seeing based on the process of data collection. However, analysis seems to correspond to homogeneous test. In other words, it is being given description as saying that 'significant difference was shown in demographic characteristics' based on $\chi^{2}$ statistics and $\mathrm{p}^{-}$-value, but was very wrong. In this way, many researches are having wrong analysis on the outcome of independent test as saying of having significant difference between two variables. Definite hypothesis establishment needs to be preceded because of being hypothetical test. By the way, a case couldn't be nearly found that established and tested hypothesis.

\section{〈Table 6〉 The cross table of marriage appearance and the fashion luxury brand segmented group}

\begin{tabular}{|c|c|c|c|c|c|}
\hline & $\begin{array}{c}\text { Loyal- } \\
\text { Heavy }\end{array}$ & $\begin{array}{c}\text { Loyal- } \\
\text { Light }\end{array}$ & $\begin{array}{c}\text { Switching- } \\
\text { Heavy }\end{array}$ & $\begin{array}{c}\text { Switching- } \\
\text { Light }\end{array}$ & x2 \\
\hline Married & 34 & 67 & 53 & 48 & $8.155\left({ }^{*}\right)$ \\
Single & 22 & 32 & 46 & 17 & \\
\hline
\end{tabular}

\section{Conclusion}

Recently almost all the researches are using a statistical method as part of a means for objectifying the results. Even non-majors in statistics in this process tend too much use of statistical package, which was made by considering convenience of usage. By the way, users fail to be knowledgeable enough in basic statistics. Thus, the possibility is getting higher that it will report wrong outcome that occurred mistakenly in the analytical process. There is a need for using after certain confirmation whether hypothesis for applying the method was satisfied or not when applying statistical method. However, the statistical package doesn't offer procedure of confirming this hypothesis [11]. This study was carried out in order to be conducive to increasing scientific characteristic and ethics of the findings through right use of statistical method. The findings are as follows. First, the error, which is shown in the application of statistical method or in the process of applying statistical package, wasn't exceptional even in a research related to clothing and textiles. Accordingly, this study examined about statistical errors, which may often occur in the research process targeting the Journal of the Korean Society of Clothing and Textiles. As a result, it confirmed that there are many errors by each stage. Second, it is a point that there wasn't any research that mentioned on power analysis in the researches, which test the appearance of significance based on the collected data through experiment or survey. A reason that the power analysis is important is because a problem of sample size determination is important element in the aspect of possibly reducing a risk, which will cause type 1 error, along with external validity of a research. Third, it was having mechanical description monotonously as well as not applying right analytical method in factor analysis. Also, even in case of cross tabulation, there was no hypothesis establishment. Moreover there were many cases of being confused contents of test. 
However, this study has limitation of research targeting the Journal of the Korean Society of Clothing and Textile during the fixed period, thereby being likely unreasonable to generalize even the results of other academic journals related to clothing and textiles. Hence, an in-depth research will need to be progressed on statistical errors by society itself even as for other academic journals related to clothing and textiles.

\section{REFERENCES}

[1] K. Choi, A reviews on the proper use of statistical methods in English education research. Studies on Ernest Hemingway and World Language \& Literature Vol. 14, pp.185-195, 2011.

[2] M. S. Chung, The effects of vanity and marital satisfaction on clothing behavior Journal of the Korean Society of Clothing and Textiles. Vol. 35, No. 3, pp. 347-35, 2011.

[3] J. Cohen, Statistical power analysis for the behavioral sciences, Wiley, New York. 1997.

[4] J. Cohen, Statistical power analysis for the behavioral sciences (2nd ed.), Lawrence Erlbaum Associates, New York. 1998.

[5] S. Ingeborg, Fehler und Fallen der Statistik (N. G. Jo, Trans.), Jungangjucksung, Seoul, 2011.

[6] H J. Jung, Y. R. Lee, The expected values of appearance management of $20 \mathrm{~s}-30 \mathrm{~s}$ and $40 \mathrm{~s}-50 \mathrm{~s}$ male consumers on their men's suit buying behavior. Journal of the Korean Society of Clothing and Textiles. Vol. 35, No. 2, pp. 125-135, 2011.

[7] J. W. Kim, S. Y. Jin, Fashion attitude and bag purchase behavior males of 20s-30s. Journal of the Korean Society of Clothing and Textiles. Vol. 35, No. 3, pp. 267-280, 2011.

[8] E. Lee, N. Yim, H. Park, Medical Care Research and Statistical Analysis, 3rd edition. Sumoonsa, Seoul, 1998.

[9] H. K. Moon, C. R. Youn, Adolescents perception of Korean traditional culture and the image association with fashion cultural products of Korea image. Journal of the Korean Society of Clothing and Textiles. Vol. 35, No. 1, pp. 51-62, 2011

[10] D. G. Park, Y. G. Kim, S. W. Shin, An assessment of statistical errors of articles in the journal of Korean academy of prosthodontics : Comparison between Korean version and English version. The Journal of Korean Academy of Prosthodontics. Vol. 47, No. 3, pp. 273-285. 2009.

[11] E. S. Park, A proposal of correct use of statistics in biomedical research. Korean Journal of Clinical Pharmacy. Vol. 17, pp. 96-101, 2007.

[12] H. G. Park, S. H. Park, Fashion and beauty involvement according to a conspicuous consumption tendency. Journal of the Korean Society of Clothing and Textiles. Vol. 35, No. 1, pp. 77-88, 2011.

[13] H. C. Park, D. H. Choi, Statistical errors in paper published in the journal of the Korean society for therapeutic radiology and oncology. The Journal of the Korean Society for Therapeutic Radiology and Oncology. Vol. 26, No. 4, pp. 289-294, 2008.

[14] S. A. Ryu, G. S. Park, H. K. Kim, A study on alteration behavior by high school students satisfaction for school uniforms. Journal of the Korean Society of Clothing and Textiles Vol. 35, No. 4, pp. 442-454, 2011.

[15] C. Shin, C. Han, C. Pae, Tools for quality evaluation of clinical research reports The Korean Journal of Psychopharmacology. Vol. 22, No. 2, pp. 67-72, 2011.

[16] E. H. Seo, SPSS Statistical Analysis . Seoul: Freedom Academy, 2005.

[17] Y. H. Shim, H. W. Yim, Sample size computation using excel in Clinical Researches. Seoul: Guja, 2009.

[18] H. S. Kim, H. G. Moon, H. J. Choo, N. H. Yoon, The effect of fashion luxury consumption values on the intention to maintain brand relationshipsDifferences among segmented markets based on purchasing patterns. Journal of the Korean Society 
of Clothing and Textiles, Vol. 35, No. 4, pp. 408-420. 2011.

\section{최 경 호(Choi, Kyoung Ho)}

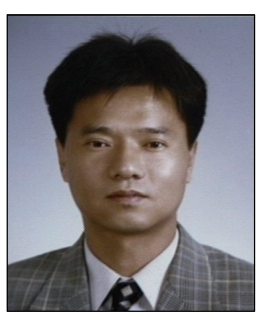

- 1985년 2월 : 전북대학교 전산통계 학과(이학사)

· 1991년 2월 : 동국대학교 통계학과 (이학석사)

· 1995년 2월 : 서울대학교 계산통계 학과(이학박사)

· 1993년 3월 현재 : 전주대학교 기 초의과학과 교수

- 관심분야 : 통계조사, 사회연결망분석, 데이터 테크놀로지

·E-Mail : ckh414@jj.ac.kr

\section{최 진 희(Choi, Jin Hee)}

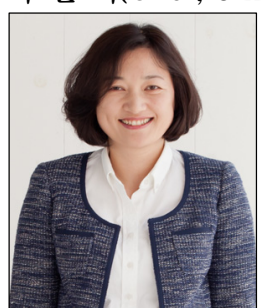

- 1994년 2월 : 이화여자대학교 의류 직물학과(가정학사)

·2002년 2월 : 이화여자대학교 의류 직물학과(이학박사)

- 2002년 9월 현재 : 전주대학교 패 션산업학과 교수

·E-Mail : jhchoi@jj.ac.kr 